\title{
Analisis Intensitas Kebisingan Terhadap Pendengaran Pekerja Pabrik Kelapa Sawit PT. Ganda Buanindo Kabupaten Kampar
}

\author{
Irwan Herli ${ }^{1}$, Tengku Nurhidayah ${ }^{2}$, Yusni Ikhwan Siregar ${ }^{2}$ \\ ${ }^{1}$ Dokter PUSKESMAS Kampar Kiri Hulu Jl. Pulai No. 27 Gema, Kecamatan Kampar Kiri Hulu \\ ${ }^{2}$ Program Studi Ilmu Lingkungan Universitas Riau Jl. Pattimura No.09.Gobah, 28131. Telp 0761-23742
}

\begin{abstract}
Work as a palm oil mill worker is a job at risk of exposure to noise that exceeds the threshold value. The purpose of this study was to measure the intensity of noise on the occurrence of hearing complaints, psychological disturbances and Noise Induced Hearing Loss (NIHL) on workers and analyze the relationship of worker characteristics; age, length of service, use of Ear Protective Equipment (EPE) and knowledge of hearing complaints, psychological disorders and NIHL disorders. The research approach used in this research is survey method using cross sectional analytic research design with sampling using purposive sampling technique as many as 40 workers. Data were collected by measuring noise intensity, questionnaires and audiometry inspection. Data analysis using univariate and bivariate analyzes were processed using Spearman test. The result of the research shows that there is a considerable noise hazard in the work environment of PT. GBI, while the potential impact experienced by workers due to noise in low risk levels. The relation between factory noise intensity and worker characteristic; age, working period, knowledge and compliance of EPE usage in general have no significant relation to the incidence of hearing complaints, psychological disorders and NIHL disorders in workers, except in the variable level of knowledge with psychological disorders have a significant relationship.
\end{abstract}

Key Words: palm oil mill noise, hearing complaints, psychological disorders, NIHL disorders

Pabrik Kelapa Sawit (PKS) adalah salah satu rantai pasok produksi di industri kelapa sawit yang berfungsi sebagai pos pengolahan tandan buah segar sawit (TBS) menjadi minyak sawit mentah/Crude Palm Oil (CPO) (Perdamean, 2014).

Pekerjaan pada paparan bising melampaui batas yang diperkenankan dan berlangsung dalam waktu yang lama maka tanpa disadari dapat menyebabkan gangguan pendengaran yang dapat berpengaruh luas dari komunikasi dan kenikmatan kerja sampai pada cacat dan kehilangan daya dengar yang menetap yang pada akhirnya akan berpengaruh terhadap kualitas kerja (Budiono, 2008).

Tujuan penelitian mengukur intensitas kebisingan terhadap kejadian keluhan pendengaran, gangguan psikologis dan gangguan Noise Induced Hearing Loss (NIHL) pada pekerja serta menganalisis karakteristik pekerja; umur, masa kerja, kebiasaan pemakaian Alat Pelindung Telinga (APT) dan pengetahuan terhadap kejadian keluhan pendengaran, gangguan psikologis dan gangguan NIHL

\section{BAHAN DAN METODE}

Penelitian ini dilakukan di PKS PT. GBI Kampar. Penelitian dilakukan selama 8 bulan, pada bulan Februari sampai dengan bulan Oktober 2017. Metode penelitian yang digunakan dalam penelitian ini adalah metode survey observasional dengan pendekatan cross sectional. Populasi penelitian terdiri dari 164 orang yang merupakan jumlah keseluruhan pekerja pada PKS PT. GBI. Kriteria inklusi dalam penelitian ini adalah pekerja dengan masa kerja lebih dari 1 tahun, mengikuti Medical Check Up (MCU) audiometri pada tahun 2017, umur $>20$ tahun dan bersedia menjadi responden penelitian. Kriteria eklusi dalam penelitian ini adalah pekerja dengan masa kerja kurang dari 1 tahun, pekerja dengan umur kurang 20 tahun dan ada riwayat menderita gangguan telinga sebelumnya. Teknik pengambilan sampel yang digunakan pada penelitian adalah Purposive sampling kepada semua pekerja di PKS PT. GBI Kampar yang terpapar kebisingan yang sudah melaksanakan MCU tahun 2017 berjumlah 43 orang, karena 
kriteria eksklusi dikurangi jumlah sampel 3 orang dan jumlah sampel akhir adalah 40 orang. Teknik pengumpulan data pada penelitian ini adalah melalui observasi, pengisian kuesioner dan pemeriksaan audiometri. Analisis data yang digunakan yaitu analisa data secara univariat dan bivariat yang diolah dengan menggunakan Uji Spearman.

\section{HASIL}

Gambaran Umum. PT. GBI adalah perusahaan milik swasta berlokasi di Desa Lipatkain Selatan Kecamatan Kampar Kiri Kabupaten Kampar Provinsi Riau. PT. GBI yang bergerak pada bidang Agroindustri dengan komoditas utama adalah Kelapa Sawit. Arah pengembangan kelapa sawit dilakukan melalui usaha budidaya dan pengolahan (PT Ganda Buanindo, 2016).

Budidaya kelapa sawit PT. GBI mempunyai kebun inti seluas $2.710 \mathrm{Ha}$, sebagai upaya pemberdayaan masyarakat setempat PT. GBI juga mengusahakan kebun plasma dengan pola kemitraan dan koperasi (PT Ganda Buanindo, 2016).

Pengolahan oleh PKS PT. GBI memiliki kapasitas produksi 45 ton/jam yang berupa produksi minyak sawit mentah/crude palm oil (CPO) sementara kernel (inti) yang dihasilkan dijual kepada pihak ketiga (Arifiarachman, 2016).

Visi dari PT. GBI adalah berusaha menjadi perusahaan perkebunan produktif dan efisien, sedangkan Misi dari PT. GBI adalah menambah nilai bagi stake holder dibidang agribisnis dan menghasilkan minyak lestari (PT Ganda Buanindo, 2016).

Sumber kebisingan. Sumber kebisingan di PKS PT. GBI berasal dari tempat kerja masing-masing unit/stasiun dan bisa juga bersumber dari kebisingan di tempat pekerjaan lain, seperti Tabel 1.
Tabel 1. Sumber kebisingan berdasarkan tempat kerja

\begin{tabular}{|c|c|c|}
\hline No & Stasiun & Sumber Kebisingan \\
\hline 1 & Loading Ramp & $\begin{array}{llr}\text { 1. } & \text { Buah jatuh di loading ramp } \\
\text { 2. } & \text { Bunyi Mesin transfer troully } \\
\text { 3. } & \text { Bunyi buah bergeser di lori } \\
\text { 4. } & \text { Bunyi Lingkungan sekitar } \\
& \text { pabrik khususnya dari } \\
& \text { sterillizer }\end{array}$ \\
\hline 2 & Sterillizer & 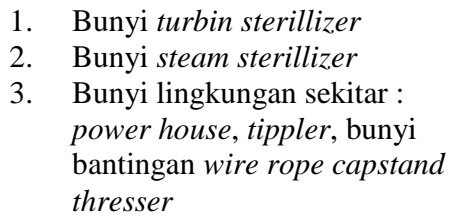 \\
\hline 3 & $\begin{array}{l}\text { Thresher } \\
\text { (Pemipilan) }\end{array}$ & $\begin{array}{l}\text { 1. Bunyi hoisting crane } \\
\text { 2. } \quad \text { Bunyi lingkungan sekitar : } \\
\text { power house, boiler, kernel }\end{array}$ \\
\hline 4 & $\begin{array}{l}\text { Pressing } \\
\text { (Pengempaan) }\end{array}$ & $\begin{array}{l}\text { 1. } \begin{array}{l}\text { Bunyi fruit distributing } \\
\text { conveyor }\end{array} \\
\text { 2. } \\
\text { Bunyi Lingkungan sekitar: } \\
\text { power house, boiler, kernel. }\end{array}$ \\
\hline 5 & Klarifikasi & $\begin{array}{l}\text { 1. Bunyi power house } \\
\text { 2. Bunyi kernel } \\
\text { 3. Bunyi boiler }\end{array}$ \\
\hline 6 & Nut and Kernel & $\begin{array}{l}\text { 1. Bunyi power house } \\
\text { 2. Bunyi kernel } \\
\text { 3. Bunyiboiler }\end{array}$ \\
\hline
\end{tabular}

Sumber kebisingan di PKS PT. GBI sejalan dengan pendapat Wiyadi (1987) pada tempat-tempat industri, sesuatu yang mengancam pendengaran manusia ialah suara bising yang ditimbulkan oleh suara mesin pabrik atau suara-suara lain yang ditimbulkan oleh pekerjaan-pekerjaan pada industri tersebut. Suara bising akan menimbulkan gangguan pendengaran.

Tingkat Kebisingan. Penelitian yang dilakukan yaitu pada daerah yang beresiko pada kebisingan di PKS PT. GBI, pekerja yang diteliti yaitu pada unit; proses, maintenance dan laboratorium, seperti pada Tabel 2.

Tabel 2.Tingkat Kebisingan dimasing-masing Unit/Stasiun

\begin{tabular}{cllc}
\hline No & Unit & $\begin{array}{l}\text { Stasiun/pek } \\
\text { erjaan }\end{array}$ & $\begin{array}{c}\text { Tingkat } \\
\text { Kebisingan }\end{array}$ \\
\hline $\mathbf{1}$ & Proses & Boiler & 83 \\
& & Klarifikasi & 89 \\
& & Kernellery & 93 \\
& & Pressing & 87 \\
& & Despact & 93 \\
& & Sortasi & 74 \\
& & Loading & 87 \\
& & ramp & \\
$\mathbf{2}$ & \multirow{4}{*}{ Maintenance } & Incinerator & 87 \\
& & Mekanik & 74 \\
$\mathbf{3}$ & \multirow{2}{*}{ Laboratorium } & Electrical & 74 \\
& & Sampel boy & 93 \\
& & Sampel girl & 93 \\
& & Despact & 93 \\
\hline
\end{tabular}


Tingkat kebisingan di masing-masing unit/stasiun lingkungan kerja pada objek penelitian dikelompokkan atas 2 bagian, dengan kriteria tingkat kebisingan yang melebihi NAB yaitu pada stasiun/pekerjaan klarifikasi, pressing, despact, loading ramp, incinerator, sampel boy dan sampel girl. Tingkat kebisingan yang tidak melebihi NAB didapati pada stasiun/pekerjaan boiler, sortasi, mekanik dan electrical. Kebisingan yang diterima pekerja melebihi NAB sebanyak 26 orang (65\%) dan kebisingan yang diterima pekerja tidak melebihi NAB sebanyak 14 orang (35\%).

Acuan dalam penentuan NAB tingkat.

Kebisingan lingkungan kerja mengacu kepada peraturan menteri tenaga kerja Nomor 13 Tahun 2011 merekomendasikan bahwa pekerjaan yang optimal adalah $<8$ jam sehari dan atau bekerja selama 40 jam dalam satu minggu dengan tingkat kebisingan $85 \mathrm{dBA}$

Dasar pemikiran perlunya penerapan aturan tentang NAB tingkat kebisingan faktor fisik lingkungan kerja karena salah satu akibat yang ditimbulkan oleh teknologi modern karena peningkatan industri adalah timbulnya masalah kebisingan yang mempunyai pengaruh luas, mulai dari gangguan konsentrasi, komunikasi dan kenikmatan kerja sampai pada cacat dan kehilangan daya dengar yang menetap. Kebisingan tidak hanya berpengaruh terhadap kualitas kerja tetapi juga berpengaruh terhadap tenaga kerja (Budiono et al., 2003).

Gambaran Karakteristik Pekerja. Gambaran karakteristik pekerja di PT. GBI terdiri dari faktor umur, masa kerja, lama kerja dalam sehari, pengetahuan tentang kebisingan dan kepatuhan penggunaan APT dapat dilihat pada Tabel 3.

Tabel 3. Gambaran Karakteristik Pekerja

\begin{tabular}{|c|c|c|c|c|}
\hline No & $\begin{array}{c}\text { Karak } \\
\text { teristik }\end{array}$ & Kelompok & $\begin{array}{c}\text { Jumlah } \\
\text { Orang }\end{array}$ & $\begin{array}{c}\text { Persentase } \\
(\%)\end{array}$ \\
\hline \multirow[t]{3}{*}{1} & Umur & Dewasa Tua & 7 & 17,5 \\
\hline & & Dewasa Pertengahan & 15 & 37,5 \\
\hline & & Dewasa Muda & 18 & 45 \\
\hline \multirow[t]{2}{*}{2} & $\begin{array}{l}\text { Masa } \\
\text { Kerja }\end{array}$ & $\begin{array}{l}\text { Kerja Lama (> } 5 \\
\text { tahun) }\end{array}$ & 24 & 60 \\
\hline & & Baru ( $\leq 5$ tahun $)$ & 16 & 40 \\
\hline \multirow[t]{2}{*}{3} & Lama & $>8$ jam & 11 & 27,5 \\
\hline & $\begin{array}{l}\text { Kerja } \\
\text { dalam } \\
\text { Sehari }\end{array}$ & $\leq 8 \mathrm{jam}$ & 29 & 72,5 \\
\hline \multirow[t]{2}{*}{4} & Pengetah & Tidak Tahu & 22 & 55 \\
\hline & uan & Tahu & 18 & 45 \\
\hline \multirow[t]{2}{*}{5} & Penggun & Tidak Patuh & 0 & 0 \\
\hline & aan APT & Patuh & 40 & 100 \\
\hline
\end{tabular}

Aturan tentang kewajiban pemakaian alat pelindung telinga sudah diwajibkan kepada setiap pekerja yang bekerja di area bising dengan mewajibkan setiap pekerja memakai ear plug di area bising dan pemakaian ear muff di area kebisingan tinggi. Aturan tentang penggunakan APD mengacu kepada Permenakertrans Nomor Per.08/Men/VII/2010 tentang Alat Pelindung Diri yaitu Pasal 2 ayat 1 menerangkan bahwa Pengusaha wajib menyediakan APD bagi pekerja/buruh di tempat kerja dan Pasal 4 ayat 1 menerangkan bahwa APD wajib digunakan di tempat kerja

Kepatuhan penggunaan APT oleh pekerja di PKS PT. GBI dengan menggunakan ear plug atenuasi $50 \%$ bisa mengurangi kebisingan 15 dBA (Buntarto, 2015). Tingkat kebisingan tertinggi di tempat penelitian PKS PT. GBI 93 dBA dikurangi $15 \mathrm{~dB}$ didapati tingkat kebisingan yang diterima pekerja dalam batas aman, sedangkan bila bekerja didaerah power house dengan tingkat kebisingan $97 \mathrm{dBA}$ pihak perusahaan mewajibkan pemakaian ear muff, dimana ear muff tersebut bisa mereduksi suara frekuensi $2800-4000 \mathrm{~Hz}$ sebesar 35-45 dB (Suardi, 2005). Hal ini merupakan faktor protektif pada pekerja di area power house untuk terhindar dari penyakit gangguan pendengaran.

\section{PEMBAHASAN}

Hubungan intensitas kebisingan terhadap keluhan pendengaran pada pekerja. Menurut Davis dan Cornwell (1991) dalam Sofiah (2011) kebisingan dapat menyebabkan dampak non auditorik, berupa gangguan pendengaran yang bersifat subjektif. Keluhan pendengaran tersebut yaitu deteriosasi wicara, keletihan, cenderung untuk mendominasi pembicaraan, telinga berdenging dan harus berkonsentrasi dalam pembicaraan. Hubungan antara kebisingan terhadap keluhan pendengaran pada pekerja Pabrik PT. GBI dapat dilihat pada Tabel 4.

\begin{tabular}{|c|c|c|c|c|c|c|c|}
\hline \multirow[t]{3}{*}{ Kebisingan } & \multicolumn{4}{|c|}{ Keluhan pendengaran } & \multicolumn{2}{|c|}{ total } & \multirow[t]{3}{*}{$\mathbf{P}$} \\
\hline & \multicolumn{2}{|c|}{ ada } & \multicolumn{2}{|c|}{ Tidak ada } & & & \\
\hline & $\mathrm{n}$ & $\%$ & $\mathrm{~N}$ & $\%$ & $\mathrm{n}$ & $\%$ & \\
\hline $\begin{array}{l}\text { Melebihi } \\
\text { NAB }\end{array}$ & 10 & 38,5 & 16 & 61,5 & 26 & 100 & $\begin{array}{c}0,2840,17 \\
3\end{array}$ \\
\hline $\begin{array}{l}\text { Tidak } \\
\text { melebihi } \\
\text { NAB }\end{array}$ & 3 & 21,4 & 11 & 78,6 & 14 & 100 & \\
\hline
\end{tabular}


Tabel 4 memperlihatkan ada sebanyak 16 orang $(61,5 \%)$ pekerja yang bekerja di lokasi melebihi NAB tidak ada keluhan pendengaran dan pekerja yang bekerja di lokasi yang tidak melebihi NAB ada sejumlah 11 orang $(78,6 \%)$ pekerja yang tidak ada keluhan pendengaran.

Analisa data di atas didapatkan bahwa tidak ada hubungan yang signifikan antara tingkat kebisingan PKS PT. GBI dengan kejadian keluhan pendengaran dibuktikan hasil Spearman Correlation Pvalue $=0,284$ dan alpha $>$ 0,05. Dari uji statistik tingkat kebisingan dengan keluhan pendengaran mempunyai koefisien korelasi (r) 0,173, dimana hubungan tersebut dapat dikategorikan sangat rendah yang berpola positif artinya semakin tinggi NAB kebisingan semakin tinggi keluhan pendengaran

\section{Hubungan intensitas kebisingan} terhadap gangguan psikologis pada pekerja. Banyak efek psikologis dari paparan kebisingan, seperti meningkatnya stress, penurunan kepuasan dan motivasi kerja. Penelitian dalam beberapa tahun terakhir menunjukkan bahwa efek psikologis terbukti bahkan pada tingkat kebisingan moderat, terutama di kalangan pekerja yang sensitif terhadap kebisingan. Beberapa studi juga menemukan tingkat desibel kebisingan sebenarnya bukanlah penentu sejauh mana kebisingan dapat menyebabkan gangguan psikologis atau stres (SWA, 2010).

Hubungan antara kebisingan terhadap gangguan psikologis pada pekerja dapat dilihat pada Tabel 5.

Tabel 5. Hubungan intensitas kebisingan terhadap gangguan psikologis

\begin{tabular}{|c|c|c|c|c|c|c|c|c|}
\hline \multirow[t]{3}{*}{ Kebisingan } & \multicolumn{4}{|c|}{ Gangguan Psikologis } & \multirow{2}{*}{\multicolumn{2}{|c|}{ Total }} & \multirow[t]{3}{*}{$\mathbf{p}$} & \multirow[t]{3}{*}{$\boldsymbol{R}$} \\
\hline & \multicolumn{2}{|c|}{ ada } & \multicolumn{2}{|c|}{ Tidak ada } & & & & \\
\hline & $\mathrm{n}$ & $\%$ & $\mathrm{~N}$ & $\%$ & $\mathrm{n}$ & $\%$ & & \\
\hline $\begin{array}{l}\text { Melebihi } \\
\text { NAB }\end{array}$ & 3 & 11,5 & 23 & 88,5 & 26 & 100 & 0,196 & 0,209 \\
\hline $\begin{array}{l}\text { Tidak } \\
\text { melebihi } \\
\text { NAB }\end{array}$ & 0 & 0 & 14 & 100 & 14 & 100 & & \\
\hline
\end{tabular}

Tabel 5 memperlihatkan bahwa sebanyak 23 orang $(88,5 \%)$ pekerja yang bekerja di lokasi melebihi NAB tidak ada gangguan psikologis. Sedangkan pekerja yang bekerja di lokasi yang tidak melebihi NAB ada sejumlah 14 orang (100\%) pekerja yang tidak ada keluhan pendengaran.
Berdasarkan data di atas didapatkan bahwa tidak ada hubungan yang signifikan antara tingkat kebisingan pabrik kelapa sawit PT. GBI dengan kejadian gangguan psikologis dibuktikan hasil Spearman Correlation $P$ value $=0,196$ dan alpha >0,05. Dari uji statistik tingkat kebisingan dengan gangguan psikologis mempunyai koefisien korelasi (r) 0,209, dimana hubungan tersebut dapat dikategorikan rendah yang berpola positif artinya semakin tinggi NAB kebisingan semakin tinggi gangguan psikologis.

Hasil yang berbeda didapatkan oleh Kristiyanto et al.(2014) yang meneliti pekerja yang mengalami gangguan psikologis meliputi gangguan konsentrasi, gangguan tidur dan perasaan mudah marah/emosi. Terdapat hubungan yang bermakna antara intensitas kebisingan dengan gangguan psikologis.

Hubungan Antara intensitas kebisingan terhadap gangguan NIHL pada Karyawan Pabrik PT. GBI. Gangguan NIHL disebabkan akibat terpajan oleh bising yang cukup keras dalam jangka waktu lama dan biasanya diakibatkan oleh bising lingkungan kerja. Bising yang intensitasnya $85 \mathrm{~dB}$ atau lebih dapat mengakibatkan kerusakan corti pada reseptor pendengaran Corti di telinga dalam. Yang sering mengalami kerusakan adalah alat Corti untuk reseptor bunyi yang berfrekuensi $3000 \mathrm{~Hz}-6000 \mathrm{~Hz}$ (Soepardi et al., 2009).

Hubungan antara intensitas kebisingan terhadap gangguan NIHL pada karyawan Pabrik PT. GBI dapat dilihat pada Tabel 6 .

Tabel 6. Hubungan intensitas kebisingan terhadap gangguan NIHL

\begin{tabular}{|c|c|c|c|c|c|c|c|c|}
\hline \multirow{3}{*}{$\begin{array}{c}\text { Kebisinga } \\
\text { n }\end{array}$} & \multicolumn{4}{|c|}{ Gangguan NIHL } & \multicolumn{2}{|c|}{ Total } & \multirow[t]{3}{*}{$\mathbf{p}$} & \multirow[t]{3}{*}{$r$} \\
\hline & \multicolumn{2}{|c|}{ ada } & \multicolumn{2}{|c|}{ Tidak ada } & & & & \\
\hline & $\mathrm{n}$ & $\%$ & $\mathrm{~N}$ & $\%$ & $\mathrm{n}$ & $\%$ & & \\
\hline $\begin{array}{l}\text { Melebihi } \\
\text { NAB }\end{array}$ & 1 & 3,8 & 25 & 96,2 & 26 & 100 & 0,470 & 0,118 \\
\hline $\begin{array}{l}\text { Tidak } \\
\text { melebihi } \\
\text { NAB }\end{array}$ & 0 & 0 & 14 & 100 & 14 & 100 & & \\
\hline
\end{tabular}

Tabel 6 memperlihatkan bahwa sebanyak 25 orang $(92,6 \%)$ pekerja yang bekerja di lokasi melebihi NAB tidak ada gangguan NIHL. Sedangkan pekerja yang bekerja di lokasi yang tidak melebihi NAB ada sejumlah 14 orang $(100 \%)$ pekerja yang tidak ada gangguan NIHL. 
Analisa data didapatkan bahwa tidak ada hubungan yang signifikan antara tingkat kebisingan pabrik kelapa sawit PT. GBI dengan kejadian gangguan NIHL dibuktikan hasil Spearman Correlation $\mathrm{P}$ value $=0,470$ dan alpha $>0,05$. Uji statistik tingkat kebisingan dengan gangguan NIHL mempunyai koefisien korelasi (r) 0,118, dimana hubungan tersebut dapat dikategorikan sangat rendah yang berpola positif artinya semakin tinggi NAB kebisingan semakin tinggi gangguan NIHL.

\section{Hubungan Antara Karakteristik Responden terhadap Keluhan Pendengaran Pada Pekerja PT. GBI. Hubungan antara} karakteristik pekerja yang meliputi umur, masa kerja, pengetahuan terhadap keluhan pendengaran dapat dilihat pada Tabel 7

Tabel 7. Hubungan karakteristik pekerja terhadap keluhan pendengaran

\begin{tabular}{|c|c|c|c|c|c|c|c|c|c|}
\hline \multirow{3}{*}{$\begin{array}{c}\text { Karakteristik } \\
\text { Pekerja }\end{array}$} & \multirow[t]{3}{*}{ Kelompok } & \multicolumn{6}{|c|}{ KeluhanPendengaran } & \multirow{3}{*}{$\mathrm{p}$} & \multirow{3}{*}{$r$} \\
\hline & & \multicolumn{2}{|c|}{ Ada } & \multicolumn{2}{|c|}{ Tidakada } & \multicolumn{2}{|c|}{ Total } & & \\
\hline & & $\mathrm{n}$ & $\%$ & $\mathrm{n}$ & $\%$ & $\mathrm{n}$ & $\%$ & & \\
\hline \multirow[t]{3}{*}{ Umur } & Dewasa Tua & 4 & 57,1 & 3 & 42,9 & 7 & 100 & 0,123 & 0,248 \\
\hline & Dewasa Pertengahan & 5 & 33,3 & 10 & 66,7 & 15 & 100 & & \\
\hline & Dewasa Muda & 4 & 22,2 & 14 & 77,8 & 18 & 100 & & \\
\hline \multirow[t]{2}{*}{ MasaKerja } & Lama & 10 & 41,7 & 14 & 58,3 & 24 & 100 & 0,136 & 0,240 \\
\hline & Baru & 3 & 18,8 & 13 & 81,3 & 16 & 100 & & \\
\hline \multirow[t]{2}{*}{ Pengetahuan } & Tahu & 7 & 38,9 & 11 & 61,1 & 18 & 100 & 0,448 & 0,123 \\
\hline & Tidak Tahu & 6 & 27,3 & 16 & 72,7 & 22 & 100 & & \\
\hline
\end{tabular}

Umur. Hasil uji statistik diperoleh nilai $\mathrm{p}=0,123>\alpha(0,05)$ dapat disimpulkan tidak ada hubungan signifikan antara kelompok umur dengan keluhan pendengaran. Uji statistik umur dengan keluhan pendengaran mempunyai koefisien korelasi (r) 0,248, dimana hubungan tersebut dapat dikategorikan rendah yang berpola positif artinya semakin tua umur semakin tinggi keluhan pendengaran.

Kondisi lingkungan kerja dapat mempengaruhi kondisi faal dan psikologis tenaga kerja, dampak paparan bising menurunkan motivasi bekerja dan bersikap lebih negatif terhadap orang lain. Paparan bising juga dapat mengakibatkan rasa lelah, sakit kepala, mudah tersinggung dan penurunan konsentrasi (Rahayu et al., 2015).

Pekerja di PKS PT. GBI dominan berada pada usia dewasa muda dan dewasa pertengahan, dimana kondisi kesehatan dan fisik pada usia

tersebut masih dalam keadaan optimum. Ditunjang dengan lingkungan kerja yang efek kebisingan sudah diminimalisir dengan kepatuhan menggunakan APT sehingga tingkat kebisingan masih di bawah NAB merupakan faktor protektif untuk tidak terjadinya angka keluhan pendengaran yang tinggi.

Masa Kerja. Hasil uji statistik nilai $p=0,136>\alpha(0,05)$, dapat disimpulkan tidak ada hubungan signifikan antara masa kerja terhadap keluhan pendengaran. Uji statistik masa kerja dengan keluhan pendengaran mempunyai koefisien korelasi (r) 0,240, dimana hubungan tersebut dapat dikategorikan rendah yang berpola positif artinya semakin lama masa kerja semakin tinggi keluhan pendengaran.

Pengaruh kebisingan terhadap manusia tergantung pada karakteristik fisik, waktu keberlangsungan dan waktu kejadiannya. Pengaruh tersebut berbentuk gangguan yang dapat menurunkan kesehatan, kenyamanan, dan rasa aman manusia (Suma'mur, 2009). Kebisingan bisa mengganggu percakapan sehingga mempengaruhi komunikasi yang berlangsung baik itu melalui tatap muka ataupun via telpon (Roestam, 2004).

Masa kerja > 5 tahun mulai menunjukkan gejala gangguan pendengaran yang bisa diawali dengan keluhan pendengaran subjektif. Dalam penelitian ini didapati keluhan pendengaran subjektif masih dalam taraf rendah, hal ini bisa terjadi adanya variasi dari tiap individu pekerja baik secara genetik, kerentanan tubuh maupun lingkungan. Variasi tersebut bisa sangat besar memengaruhi kesehatan pekerja, sehingga tidak mengherankan ditemukan situasi di mana 2 (dua) orang pekerja yang bekerja pada pekerjaan, tempat dan lama bekerja yang sama, namun status atau kondisi kesehatannya tidak sama/berbeda (wibowo et al., 2014).

Pengetahuan tentang kebisingan. Secara statistik diperoleh nilai $\mathrm{p}=0,448>\alpha$ $(0,05)$ dapat disimpulkan tidak ada hubungan signifikan antara tingkat pengetahuan dengan 
keluhan pendengaran. Uji statistik pengetahuan dengan keluhan pendengaran mempunyai koefisien korelasi (r) 0,123, hubungan tersebut dapat dikategorikan sangat rendah yang berpola positif artinya semakin tinggi pengetahuan diikuti semakin tinggi keluhan pendengaran.

Pekerja yang lebih tahu bahaya bising akan perduli terhadap kesehatan dirinya maka akan merasakan efek dari kebisingan dan berusaha untuk mengantisipasi dari efek yang tidak menyenangkan tersebut sehingga pada pekerja yang tahu akan bahaya bising maka rasa peduli terhadap kesehatan diri sendiri akan semakin besar. Memberikan sosialisasi tentang bahaya bising merupakan salah satu bentuk untuk

\begin{tabular}{|c|c|c|c|c|c|c|c|c|c|}
\hline \multirow{3}{*}{$\begin{array}{c}\text { Karakteristik } \\
\text { Pekerja }\end{array}$} & \multirow{3}{*}{ Kelompok } & \multicolumn{6}{|c|}{ Gangguan Psikologis } & \multirow{3}{*}{$\mathrm{P}$} & \multirow{3}{*}{$R$} \\
\hline & & \multicolumn{2}{|c|}{ Ada } & \multicolumn{2}{|c|}{ Tidakada } & \multicolumn{2}{|c|}{ Total } & & \\
\hline & & $\mathrm{n}$ & $\%$ & $\mathrm{n}$ & $\%$ & $\mathrm{n}$ & $\%$ & & \\
\hline \multirow{3}{*}{ Umur } & Dewasa Tua & 1 & 14,3 & 6 & 85,7 & 7 & 100 & \multirow{3}{*}{0,127} & \multirow{3}{*}{0,245} \\
\hline & Dewasa Pertengahan & 2 & 13,3 & 13 & 86,7 & 15 & 100 & & \\
\hline & Dewasa Muda & 0 & 0,0 & 18 & 100 & 18 & 100 & & \\
\hline \multirow[t]{2}{*}{ MasaKerja } & Lama & 3 & 12,5 & 21 & 87,5 & 24 & 100 & \multirow{2}{*}{0,149} & \multirow{2}{*}{0,232} \\
\hline & Baru & 0 & 0,0 & 16 & 100 & 16 & 100 & & \\
\hline \multirow[t]{2}{*}{ Pengetahuan } & Tahu & 3 & 16,7 & 15 & 83,3 & 18 & 100 & \multirow{2}{*}{0,048} & \multirow{2}{*}{0,315} \\
\hline & Tidak Tahu & 6 & 27,3 & 16 & 72,7 & 22 & 100 & & \\
\hline
\end{tabular}

Umur. Hasil uji statistik diperoleh nilai $\mathrm{p}=0,127>\alpha(0,05)$ dapat disimpulkan tidak ada hubungan signifikan antara kelompok umur dengan gangguan psikologis. Uji statistik umur dengan gangguan psikolgis mempunyai koefisien korelasi (r) 0,245, hubungan tersebut dapat dikategorikan rendah yang berpola positif artinya semakin tua umur semakin tinggi gangguan psikologis.

Menurut pandangan interaktif dari stres, stres ditentukan pula oleh individunya sendiri. Reaksi-reaksi sejauh mana ia melihat situasinya sebagai penuh stres. Reaksi-reaksi psikologis, fisiologis dan dalam bentuk perilaku terhadap stres adalah hasil dari interaksi situasi dengan individunya, mencakup ciri-ciri kepribadian yang khusus dan pola-pola perilaku yang didasarkan pada sikap, kebutuhan, nilai-nilai, pengalaman masa lalu, keadaan kehidupan dan kecakapan (antara lain intelegensi, pendidikan, pelatihan, dan pembelajaran). Faktor-faktor dalam diri individu berfungsi sebagai faktor pengaruh antara rangsangan diri lingkungan yang merupakan pembangkit stres potensial dengan individu. Faktor pengubah ini yang menentukan bagaimana, dalam kenyataannya, individu bereaksi terhadap pembangkit stres potensial (Sucipto, 2014). Pendapat di atas meningkatkan kesadaran kepada pekerja yang secara terus menerus terpapar bising, dengan harapan bahwa pengetahuan mampu memberikan rasa peduli terhadap kesehatan diri maupun lingkungannya.

Hubungan antara karakteristik pekerja terhadap gangguan Psikologis pada pekerja PT. GBI. Untuk melihat hubungan antara karakteristik pekerja yang meliputi umur, masa kerja, pengetahuan terhadap gangguan psikologis dapat dilihat pada Tabel 8.

Tabel 8. Hubungan karakteristik pekerja terhadap gangguan psikologis

dapat disimpulkan faktor umur tidak mempengaruhi secara spesifik terhadap kejadian gangguan psikologi pada pekerja, faktor dominan yang mempengaruhi adalah faktor individu sendiri.

Masa kerja. Hasil uji statistik nilai $p=0,149>\alpha(0,05)$. Dapat disimpulkan tidak ada hubungan signifikan antara masa kerja terhadap gangguan psikologis. Uji statistik masa kerja dengan gangguan psikologis mempunyai koefisien korelasi (r) 0,232, hubungan tersebut dapat dikategorikan rendah yang berpola positif artinya semakin lama masa kerja semakin banyak gangguan psikologis.

Stressor lingkungan akan mengakibatkan peningkatan sekresi kortisol. Kortisol bertanggung jawab dalam sistem umpan balik negatif terhadap hipotalamus untuk menurunkan sekresi CRF (Cortisol Releasing Hormone) dan Adreno Cortico Tropic Hormone $(\mathrm{ACTH})$. Jika stressor lingkungan terus menerus terjadi maka mekanisme umpan balik negatif ini tidak mampu lagi menekan sekresi CSF dan ACTH sehingga aktivitas pada aksis HPA terus meningkat sehingga dapat merusak sel neuron di hipotalamus. Akibat yang ditimbulkan dari atrofi hipotalamus adalah munculnya gangguan kognitif seperti depresi 
dan gangguan psikologis lainnya (Spencer dan McEwen, 1990) dalam (Ramdan et al, 2014).

Faktor stressor bisa berakibat buruk, tetapi tubuh mempunyai sistem pertahanan sendiri yang disadari atau tidak disadari. Seseorang yang merasa nyaman bekerja dilingkungan tertentu atau memiliki sikap optimis bisa berdampak positif sehingga mengurangi pelepasan hormon kortisol yang faktor stress dapat dikurangi. Hal ini yang kemungkinan terjadi pada pekerja PKS PT. GBI sehingga gangguan psikologis bisa dieliminisir.

Pengetahuan tentang kebisingan. Hasil uji statistik diperoleh nilai $\mathrm{p}=0,048>\alpha(0,05)$ dapat disimpulkan ada hubungan signifikan antara pengetahuan bahaya bising dengan gangguan psikologis. Uji statistik pengetahuan dengan gangguan psikologis mempunyai koefisien korelasi (r) 0,315, hubungan tersebut dapat dikategorikan rendah yang berpola positif artinya semakin tinggi pengetahuan diikuti semakin tinggi gangguan psikologis.

Bila dihubungkan dengan pendapat Roger (1974) dalam Notoatmodjo (2005), pengetahuan merupakan suatu hasil dari

\begin{tabular}{llcc}
\hline $\begin{array}{c}\text { Karakteristik } \\
\text { Pekerja }\end{array}$ & \multicolumn{2}{c}{ Kelompok } & \multicolumn{2}{c}{ Ada } \\
& & $\mathrm{n}$ & $\%$ \\
\hline Umur & Dewasa Tua & 0 & 0 \\
& Dewasa Pertengahan & 0 & 0 \\
\multirow{4}{*}{ MasaKerja } & Dewasa Muda & 1 & 5 \\
& Lama & 1 & 4 \\
& Baru & 0 & 0 \\
& Tidak Tahu & 1 & 4 \\
& Tahu & 0 & 0 \\
\hline
\end{tabular}

Umur. Hasil uji statistik diperoleh nilai $\mathrm{p}=0,308>\alpha(0,05)$ dapat disimpulkan tidak ada hubungan signifikan antara kelompok umur dengan gangguan NIHL. Uji statistik umur dengan gangguan NIHL mempunyai koefisien korelasi (r) -0,165, dimana hubungan tersebut dapat dikategorikan sangat rendah yang berpola negatif artinya semakin tua umur tidak diikuti semakin tinggi gangguan NIHL.

Menurut Webb (1996) dalam Djafri
(2010) umur bukan faktor yang
mempengaruhi secara langsung terpajan kebisingan di tempat kerja terhadap gangguan pendengaran tetapi pada usia di atas 40 tahun telinga manusia rentan terhadap trauma, sedangkan menurut Achmadi (1994) pengindraan manusia atau merupakan suatu hasil tahu seseorang terhadap objek melalui indra yang dimilikinya dan sebagian besar pengetahuan seseorang tersebut didapat melalui indra penglihatan.

PT. GBI dengan melaksanakan pelatihan dan pemberian informasi tentang Sistem Menajemen Keselamatan dan Kesehatan Kerja (SMK3) kepada staf terkait, seterusnya staf tersebut memberikan informasi kepada pekerja di bawahnya secara berjenjang tentang K3 yang termasuk di dalamnya hazard di tempat kerja sesuai dengan jadwal yang telah ditetapkan, sewaktu penerimaan pegawai baru dan tindak lanjut penyampaian hasil MCU.

Hubungan Antara Karakteristik Pekerja terhadap Gangguan NIHL. Untuk melihat hubungan antara karakteristik responden yang meliputi umur, masa kerja, pengetahuan terhadap gangguan NIHL dapat dilihat pada Tabel 9 .

Tabel 9. Hubungan karakteristik pekerja terhadap gangguan NIHL

\begin{tabular}{|c|c|c|c|c|c|}
\hline \multicolumn{6}{|c|}{ Gangguan NIHL } \\
\hline \multicolumn{2}{|c|}{ Tidakada } & \multicolumn{2}{|c|}{ Total } & \multirow[t]{2}{*}{$\mathrm{p}$} & \multirow[t]{2}{*}{$r$} \\
\hline $\mathrm{n}$ & $\%$ & $\mathrm{n}$ & $\%$ & & \\
\hline 7 & 100 & 7 & 100 & & \\
\hline 15 & 100 & 15 & 100 & 0,308 & $-0,165$ \\
\hline 17 & 94,4 & 18 & 100 & & \\
\hline 23 & 95,8 & 24 & 100 & & \\
\hline 16 & 100 & 16 & 100 & 0,421 & 0,131 \\
\hline 21 & 95,5 & 22 & 100 & ( 272 & \\
\hline 18 & 100 & 18 & 100 & $0,3 / 3$ & 0,145 \\
\hline
\end{tabular}

dalam Djafri (2010) mengemukakan bahwa orang yang berumur > 40 tahun akan lebih mudah mengalami gangguan pendengaran akibat bising, dimana pekerja yang sudah mencapai umur > 40 tahun rentan terhadap risiko kebisingan.

Masa Kerja. Hasil uji statistik diperoleh nilai $\mathrm{p}=0,421>\alpha(0,05)$ dapat disimpulkan tidak ada hubungan signifikan antara kelompok masa kerja dengan gangguan NIHL. Uji statistik masa kerja dengan gangguan NIHL mempunyai koefisien korelasi (r) 0,131, dimana hubungan tersebut dapat dikategorikan sangat rendah yang berpola positif artinya semakin lama masa kerja semakin tinggi gangguan NIHL.

Variabel masa kerja dibatasi minimal pekerja sudah 5 tahun bekerja di tempat bising, hal ini dikarenakan paparan kebisingan $>85 \mathrm{~dB}$ 
(A) ada kemungkinan setelah 5 tahun kerja, $1 \%$ pekerja akan memperlihatkan sedikit gangguan pendengaran. Ketulian bersifat progresif atau awalnya bersifat sementara tetapi bila bekerja terus menerus di tempat bising tersebut maka daya dengar menghilang secara menetap atau tuli (Buchari, 2007 dalam winda et al., 2016), sedangkan penelitian di PKS PT. GBI penelitian pada semua pekerja yang sudah bekerja > 1 tahun, sehingga bisa jadi faktor umur belum nampak mempengaruhi gangguan NIHL.

Pengetahuan tentang kebisingan. Hasil uji statistik diperoleh nilai $\mathrm{p}=0,373>\alpha(0,05)$ dapat disimpulkan tidak ada hubungan signifikan antara pengetahuan bahaya bising dengan gangguan pendengaran. Uji statistik pengetahuan dengan gangguan NIHL mempunyai koefisien korelasi (r) 0,145, dimana hubungan tersebut dapat dikategorikan sangat rendah yang berpola positif artinya semakin tinggi ketidaktahuan (pengetahuan rendah) semakin tinggi Gangguan NIHL.

Pendekatan pendidikan baik yang dilakukan secara formal maupun tidak formal untuk memberi pengertian dan mengubah perilaku. Metode ini baik sekali karena pekerja mengerti mengapa mereka harus berubah. Apabila berhasil, mereka tidak perlu diawasi, bahkan akan ikut serta melakukan kontrol sosial. Pendekatan pendidikan ini memerlukan waktu yang lama dan perlu metode pendidikan yang efektif untuk mendapatkan hasilnya. Pendekatan administratif di dunia kerja berupa peraturan beserta sanksinya (Soemirat, 2011).

Kondisi pekerja PT. GBI didapati umumnya pekerja memiliki pengetahuan yang rendah tetapi aturan perusahaan berupa pendekatan administratif bisa meningkatkan kepatuhan pemakaian APT yang sangat baik (100\%). Kepatuhan pemakaian APT mengurangi paparan kebisingan kepada pekerja, hal ini bisa menghilangkan hazard kebisingan di lingkungan kerja dan resiko gangguan NIHL yang dialami pekerja menjadi rendah.

\section{KESIMPULAN}

Berdasarkan hasil penelitian dapat ditarik kesimpulan sebagai berikut:

1. Terdapat bahaya kebisingan yang cukup tinggi pada lingkungan kerja PT. GBI, sementara potensi dampak yang dialami pekerja akibat kebisingan dalam taraf resiko rendah. Hal ini dibuktikan hubungan intensitas kebisingan pabrik yang melebihi NAB yang diterima oleh pekerja selama melakukan pekerjaan di PKS PT. GBI tidak memiliki hubungan yang signifikan untuk terjadinya keluhan pendengaran, gangguan psikologis dan gangguan NIHL, meskipun demikian didapati kecenderungan peningkatan kejadian keluhan pendengaran, gangguan pendengaran dan gangguan NIHL pada pekerja yang bekerja di area melebihi NAB dibandingkan dengan pekerja yang bekerja di area yang tidak melebihi NAB.

2. Potensi bahaya paparan terhadap pekerja; umur, masa kerja dalam taraf resiko rendah. Pengetahuan pekerja tentang kebisingan dalam taraf rendah tetapi dengan adanya aturan perusahaan yang membuat kepatuhan pemakaian APT tinggi sehingga mengurangi paparan dosis kebisingan kepada pekerja. Hal ini dibuktikan faktor karakteristik pekerja tidak memiliki hubungan yang signifikan untuk terjadinya keluhan pendengaran, gangguan psikologis dan gangguan NIHL. Khusus untuk karakteristik pekerja yaitu faktor pengetahuan kebisingan memiliki hubungan yang signifikan untuk terjadinya gangguan psikologis. Ada kecenderungan resiko keluhan pendengaran terjadi pada pekerja berumur tua, masa kerja lama, dan pada pekerja yang memiliki pengetahuan yang baik. Kecenderungan resiko gangguan psikologis terjadi pada pekerja berumur tua, masa kerja lama dan pengetahuan baik. Kecenderungan resiko gangguan NIHL terjadi pada pekerja masa kerja lama dan pengetahuan rendah.

\section{UCAPAN TERIMA KASIH}

Ucapan terima kasih penulis sampaikan kepada semua pihak yang telah banyak membantu terlaksananya penelitian ini.

\section{DAFTAR PUSTAKA}

Arifiarachman, T. 2016. Pemberitahuan Untuk Kegiatan Penilaian Sertifikasi ISPO di PT. Ganda Buanindo. Pengumuman Publik. PT. Mutu Agung Lestari. http://www.420PengumumanPublikISPO 
STAGE-2PT.GandaBuanindo.pdf. diakses tanggal 12 November 2017

Budiono. 2008. Hiperkes dan Kesehatan Kerja. Semarang. Universitas Diponegoro.

Budiono dan A.M. Sugeng. 2003. Bunga Rampai Hiperkes dan KK. Semarang. Universitas Diponegoro.

Buntarto, 2015. Panduan Praktis Keselamatan \& Kesehatan Kerja untuk industri. Yogyakarta. Pustaka baru press

Djafri, A. 2010. Hubungan Tingkat Pajanan Kebisingan dengan Fungsi Pendengaran di PT Sanggar Sarana Baja. Tesis. Depok. FKM Program Magister Keselamatan dan Kesehatan Kerja Universitas Indonesia (tidak dipublikasikan).

Kristiyanto, F. Kurniawan, F. Wahyuni, I. 2014. Hubungan Intensitas Kebisingan Dengan Gangguan Psikologis Pekerja Departemen Laundry Bagian Washing PT. X Semarang. Semarang. JKM eJournal.2(1): Hal 75-79

Menteri Tenaga Kerja dan transmigrasi RI, 2010. Permenakertrans Nomor Per.08/Men/VII/2010 tentang alat pelindung diri. Jakarta.

Notoadmojo, S. 2005. Metode Penelitian. Jakarta. Rineka Cipta.

Pardamean, M. 2014. Mengelola Kebun dan Pabrik Kelapa Sawit secara Profesional. Jakarta; Penebar Swadaya.

PT Ganda buanindo, 2016. Utamakan Keselamatan dan Kesehatan Kerja. Lipatkain.

Rahayu D, et al. 2015. Materi Ajar Pelatihan Hiperkes Dan Keselamatan Kerja Bagi Tenaga Medis Perusahaan. Direktorat Bina Keselamatan Dan Kesehatan Kerja Direktorat Jenderal Pembinaan, Pengawasan Ketenagakerjaan Dan Keselamatan Dan Kesehatan Kerja Kementrian Ketenagakerjaan RI. Jakarta.

Ramdan. IM dan Y. Putri. 2014. Hubungan Paparan Kebisingan dengan gangguan Psikologis, gangguan komunikasi dan tekanan darah pada tenaga kerja PLTD Kasamarinda 2014. Seminar Nasional Penelitian dan Pengabdian kepada Masyarakat. Bandung.

Roestam, A.W. 2004. Program Konservasi Pendengaran di Tempat Kerja. Cermin Dunia Kedokteran No. 144, 2004.
Soemirat, J. 2011. Kesehatan Lingkungan. Yogyakarta. Gajah Mada University Press.

Sofiah, 2011. Analisis Kebisingan Pesawat Udara Dan Karakteristik Masyarakat Bandara Terhadap Gangguan Keluhan Pendengarandan Gangguan Psikologis Pada Kawasan Bandara Sultan Syarif Kasim II. Tesis. Pekanbaru: Program Studi Ilmu Lingkungan Program Pascasarjana Universitas Riau (tidak dipublikasikan).

Sopeardi et al. 2009. Buku Ajar Ilmu Kesehatan, Telinga Hidung Tenggorokan Kepala dan Leher, Edisi keenam, Fakultas Kedokteran Universitas Indonesia. Jakarta.

Suardi, R. 2005. Sistem Manajemen Keselamatan dan Kesehatan Kerja, Jakarta.Argya Putra.

Sucipto, CD. 2014. Keselamatan dan kesehatan kerja. Yogyakarta. Goysen Publishing.

Suma'mur, PK. 2009. Higiene Perusahaan dan Kesehatan Kerja (HIPERKES). Jakarta. CV. Sagung Seto.

SWA. 2010. Occupational Noise-Induced Hearing Loss In Australia. Safe Work Australia

https://www.safeworkaustralia.gov.au/syst em/files/documents/1702/occupational_no iseinduced_hearing_loss_australia_2010.p df. diakses tanggal 14 Desember 2017.

Wibowo A, et al. 2014. Kesehatan masyarakat di Indonesia konsep, aplikasi dan tantangan. PT Raja Grafindo Persada. Jakarta

Winda,WP.T. Martiana. 2016. Hubungan Usia Dan Masa Kerja Dengan Nilai Ambang Dengar Pekerja Yang Terpapar Bising Di Pt. X Sidoarjo.The Indonesian Journal of Occupational Safety and Health.5 (2) Hal 173-182. $\quad$ https://ejournal.unair.ac.id/IJOSH/article/view/418 6/2830. diakses 28 desember 2017

Wiyadi, MS. 1987. Pemeliharaan Pendengaran di Industri. Cermin Dunia Kedokteran. no.47. PT.Temprint. jakarta. 